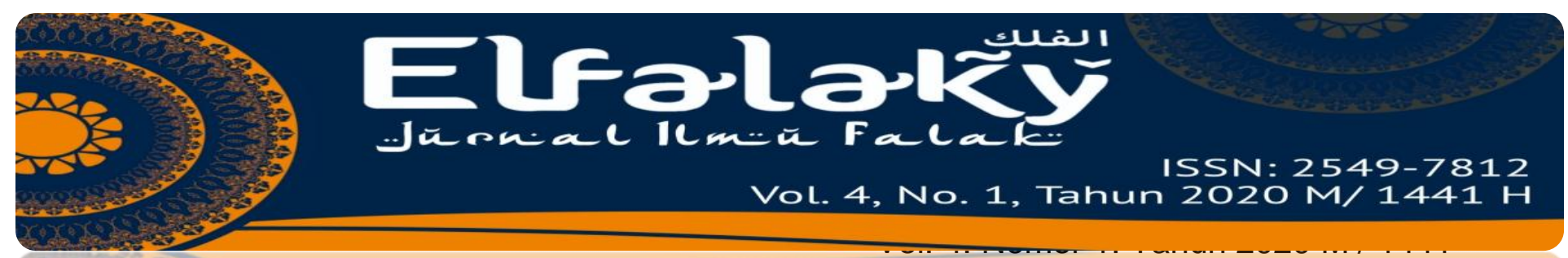

\title{
INTEGRASI TEKS-TEKS SYAR'I YANG TERKAIT DENGAN ARAH KIBLAT DALAM KONTEKS ASTRONOMI
}

\author{
Nurul Arifin \\ Prodi Hukum Keluarga Islam (Ahwal Syakhshiyyah) \\ Fakultas Syariah IAIN Pontianak \\ Email: Arifinnurul899@gmail.com
}

\begin{abstract}
ABSTRAK
Seiring dengan perkembangan teknologi dan kemajuan ilmu pengetahuan, metode menentukan arah kiblat dari masa ke masa mengalami perkembangan. Dari yang bersifat klasik sampai modern. Metode klasik seperti rashd al-qiblah (posisi matahari di atas ka'bah), menggunakan tongkat istiwa', dan berdasarkan fenomena bayangan matahari harian. Sedangkan metode yang bersifat modern, diantaranya: kompas, ilmu ukur segitiga bola (spherical trigonometri), theodolit, Global Positioning System (GPS), google earth, dan lainlain. Dengan penentuan arah kiblat berdasarkan beberapa metode di atas, tidak lepas dari petunjuk teks-teks syar'i (al-Qur'an dan hadis) dalam konteks astronomi. Misalnya Qs.Yunus (10): 5 yang menjelaskan bahwa Allah Swt menjadikan matahari bersinar. Dalam hal ini, sinar matahari tersebut berimplikasi pada bayangan matahari dan berdasarkan bayangan matahari, umat Islam dapat menentukan arah kiblatnya.
\end{abstract}

Kata Kunci: Integrasi, teks syar'i, arah kiblat, astronomi.

\section{A. Pendahuluan}

Salah satu bidang ilmu pengetahuan yang pertama kali menarik minat para ilmuwan muslim adalah astronomi. Kecenderungan terhadap bidang ini karena berkaitan langsung dengan peribadatan umat Islam. Seperti dalam menentukan awal dan akhir ibadah puasa Ramadhan, awal idul fitri, awal ibadah haji, awal dan akhir waktu shalat, sampai pada menentukan arah kiblat. Semua jenis ibadah 


\section{ELFALAKY: Jurnal Ilmu Falak}

Vol. 4. Nomor 1. Tahun $2020 \mathrm{M} / 1441$

tersebut didasarkan pada perputaran benda-benda langit, yang semua ini dibahas dalam ilmu falak atau astronomi ${ }^{1}$

Astronomi dipahami sebagai cabang ilmu pengetahuan yang dikembangkan berbasis pengamatan benda-benda langit. Objek langit yang dikaji dalam ilmu ini, meliputi tata surya seperti bulan, matahari, bumi, komet, meteor, galaksi, dan sebagainya. Peredaran benda-benda langit tersebut memiliki daya tarik bagi manusia dan menumbuhkan rasa ingin tahu yang berimplikasi pada beragam kajian tentang hukum alam tersebut.

Al-Qur'an al-karim telah memberikan petunjuk tentang hukum alam berupa ayat-ayat yang berkaitan dengan astronomi. Terdapat sejumlah ayat yang menjelaskan tentang hal ini, diantaranya adalah Qs.Yunus (10): 5-6, Qs.Yasin (36): 37-40, dan Qs. al-Jatsiyah (45): 12-13. Ayat-ayat tersebut memberikan pengetahuan bagi manusia bahwa peredaran benda-benda langit telah ditentukan tempat edarnya masing-masing.

Isyarat al-Qur'an tentang benda-benda langit di atas, berkaitan juga dengan penentuan arah kiblat. Misalnya Qs.Yunus (10): 5 yang menjelaskan bahwa Allah Swt menjadikan matahari bersinar. Dalam hal ini, sinar matahari tersebut berimplikasi pada bayangan matahari dan berdasarkan bayangan matahari, umat Islam dapat menentukan arah kiblatnya. Seiring dengan perkembangan teknologi dan kemajuan ilmu pengetahuan, sejumlah teks ayat astronomi tersebut menjadi petunjuk para ilmuwan muslim dalam menentukan metode penentuan arah kiblat.

Metode menentukan arah kiblat dari masa ke masa mengalami perkembangan. Dari yang bersifat klasik sampai modern. Metode klasik seperti rashd al-qiblah (posisi matahari di atas ka'bah), menggunakan tongkat istiwa', dan berdasarkan fenomena bayangan matahari harian. Sedangkan metode yang bersifat modern, diantaranya dengan menggunakan: kompas, ilmu ukur segitiga bola

\footnotetext{
${ }^{1}$ Abu Su'ud, Islamologi: Sejarah, Ajaran, dan Peranannya dalam Peradaban Umat Manusia (Jakarta: Rineka Cipta, 2003), p. 201.
} 


\section{ELFALAKY: Jurnal Ilmu Falak}

Vol. 4. Nomor 1. Tahun $2020 \mathrm{M} / 1441$

(spherical trigonometri), theodolit, Global Positioning System (GPS), google earth, dan lain-lain.

Beragam penentuan arah kiblat berdasarkan beberapa metode di atas, tidak lepas dari petunjuk teks-teks syar'i (al-Qur'an dan hadis) dalam konteks astronomi. Atas dasar ini, peneliti akan mengurai lebih dalam tentang integrasi teks-teks syar'i dan ilmu astronomi yang berkaitan dengan penentuan arah kiblat. Adapun metode yang peneliti tempuh dalam menyelesaikan artikel ini adalah menggunakan pendekatan normatif-deskriptif. Artinya, teks-teks syar'i tentang arah kiblat menjadi norma atau aturan bagi peneliti dalam mendeskripsikan kajian ini.

\section{B. Konsep Arah Kiblat}

Istilah kiblat berasal dari kata bahasa arab "qiblah" merupakan bentuk masdar dari kata qabbala, yuqabbilu, qiblah, berarti menghadap. ${ }^{2}$ Dalam Kamus Besar Bahasa Indonesia (KBBI), kiblat bararti arah ke Ka'bah di Mekkah (pada waktu shalat). ${ }^{3}$ Begitu juga di dalam al-Qur'an, kata kiblat berarti arah, terdapat dalam Q.S al-Baqarah (2): 142-145 dan berarti tempat, terdapat dalam Q.S Yunus (10): $87 .^{4}$

Sedangkan menurut Harun Nasution dalam Muhammad Hadi Bashori, kiblat adalah arah untuk menghadap pada waktu shalat. ${ }^{5}$ Sedangkan menurut Mochtar Effendy dalam Muhammad Hadi Bashori, mengartikan sebagai arah shalat, yaitu arah Ka'bah di kota Mekkah ${ }^{6}$. Sementara menurut Slamet Hambali dalam Muhammad Hadi Bashori, kiblat adalah arah menuju Ka'bah (Mekkah)

\footnotetext{
${ }^{2}$ Ahmad Warson Munawwir, Kamus Al-Munawwir (Surabaya: Pustaka Progressif, 1997), p. 1088.

${ }^{3}$ Pusat Bahasa Dapartemen Pendididkan Nasional, Kamus Bahasa Indonesia (Jakarta: Pusat Bahasa, 2008), p. 721.

${ }^{4}$ Dahlia Haliyah, 'Penentuan Arah Kiblat (Dari Metode Klasik Ke Modern)', Jurnal Hukum Islam, 1.2 (2013), p. 114.

${ }^{5}$ M. Hadi Bashori, Pengantar Ilmu Falak (Jakarta Timur: Pustaka al-Kautsar, 2015), p. 113.

${ }^{6}$ Bashori, p. 114.
} 


\section{ELFALAKY: Jurnal Ilmu Falak}

Vol. 4. Nomor 1. Tahun $2020 \mathrm{M} / 1441$

melewati jalur terdekat yang mana setiap muslim ketika shalat harus menghadapnya ${ }^{7}$.

Dari definisi diatas, dapat disimpulkan bahwa kiblat adalah arah terdekat dari titik atau tempat menuju Ka'bah dan setiap Muslim wajib menghadap kiblat ketika melaksanakan shalat. Maksud arah terdekat, dikarenakan bumi mirip seperti bola, maka hanya ada dua jalur untuk menghadap dan membelakangi Ka'bah, maka dari itu jarak terdekat adalah arah menghadap kiblat. sedangkan yang dimaksud dengan titik atau tempat menuju Ka'bah yaitu tempat yang akan di ukur arah kiblatnya, karena setiap koordinat tempat berbeda-beda. Kemudian setiap muslim wajib menghadap kiblat ketika shalat, karena menjadi syarat sah shalat.

\section{Teks-Teks Syar'i tentang Arah Kiblat}

Terdapat beberapa ayat al-Qur'an dan hadis yang berkaitan dengan arah kiblat, yaitu:

1. Dasar hukum dari al-Qur'an

a. Firman Allah SWT dalam Q.S al-Baqarah (2) ayat 144:

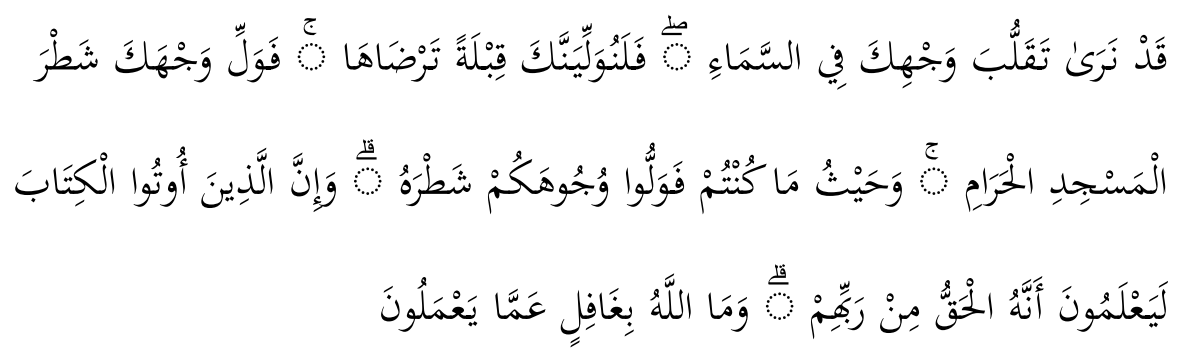

Sesungguhnya kami melihat wajahmu (Muhammad) sering menengadah ke langit, maka akan kami palingkan engkau ke kiblat yang engkau senangi. Maka hadapkanlah wajahmu ke arah Masjidilharam. Dan di mana saja engkau berada, hadapkanlah wajahmu ke arah itu. Dan sesungguhnya orang-orang yang diberi Kitab (Taurat dan Injil) tahu, bahwa (pemindahahan kiblat) itu adalah kebenaran dari Tuhan mereka. Dan Allah tidak lengah terhadap apa yang mereka kerjakan.

\footnotetext{
${ }^{7}$ Bashori, p. 114.
} 


\section{ELFALAKY: Jurnal Ilmu Falak}

Vol. 4. Nomor 1. Tahun 2020 M / 1441

b. Firman Allah SWT dalam Q.S al-Baqarah (2) ayat 149:

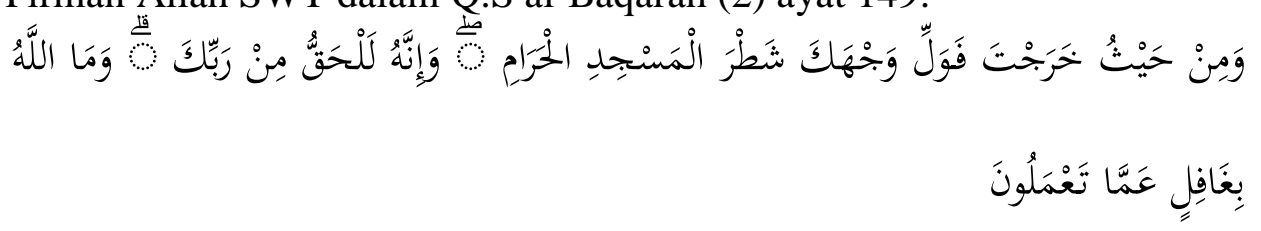

Dan dari mana pun engkau (Muhammad) keluar, hadapkanlah wajahmu ke arah Masjidilharam, sesungguhnya itu benar-benar dari Tuhanmu. Allah tidak lengah terhadap apa yang kamu kerjakan.

c. Firman Allah SWT dalam Q.S al-Baqarah (2) ayat 150:

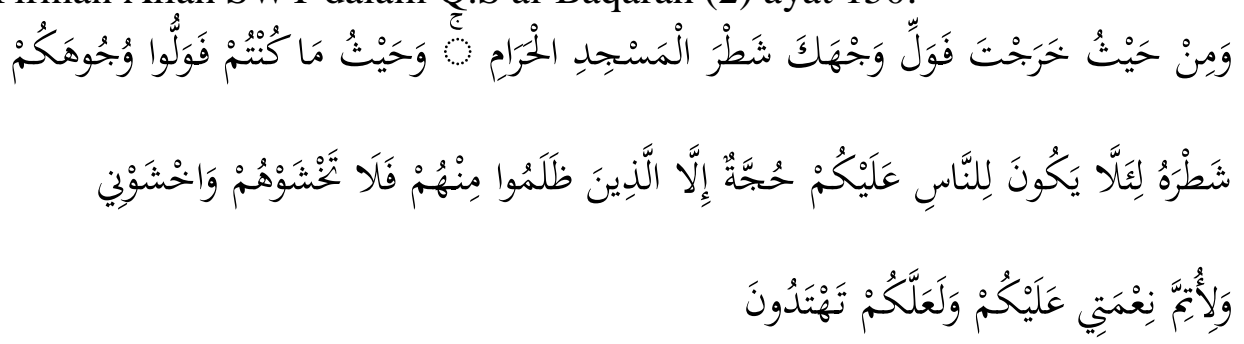

Dan dari mana pun engkau (Muhammad) keluar, maka hadapkanlah wajahmu ke arah itu, agar tidak ada alasan bagi manusia (untuk menantangmu), kecuali orang- orang yang zalim di antara mereka. Janganlah kamu takut kepada mereka, tetapi takutlah kepada-Ku, agar Aku sempurnakan nikmat-Ku kepadamu, dan agar kamu mendapat petunjuk.

2. Dasar hukum dari al-Hadits

a. Hadits riwayat Imam Bukhari: ${ }^{8}$

$$
\text { قال ابو هريرة رضي الله تعال عنه قال : قال رسول الله صلالله عليه وسلم : اسشتقبل }
$$

"Dari Abi Hurairah r.a berkata: Rasulullah SAW bersabda: "menghadaplah ke kiblat lalu takbir" (HR. Bukhari).

${ }^{8}$ Sayful Mujab, 'Kiblat dalam Perspektif Madzhab-Madzhab Fiqh', Pemikiran Hukum dan Hukum Islam, 5.2 (2014), 27 p. 340. 


\section{ELFALAKY: Jurnal Ilmu Falak}

Vol. 4. Nomor 1. Tahun 2020 M / 1441

b. Hadits riwayat Imam Muslim: ${ }^{9}$

$$
\begin{aligned}
& \text { حدثنا ابوبكرابن شيبة حدثنا عفان حدثنا حماد بن سلمة عن ثابت عن أنس أن رسول الله } \\
& \text { صلى الله عليه وسلم كان يصلي نحو بيت المقدس فنزلت " قد نرى تقلب وجهك فن } \\
& \text { السماء فلنولينك قبلة ترضها فول وجهك شطر المسجد الحرام " فمر رجل من بنى سلمة } \\
& \text { وهم ركوع فن صلاة الفجر وقد صلوا ركعة فنادى ألا ان القبلة قد حولت فمالوا كماهم نحو }
\end{aligned}
$$

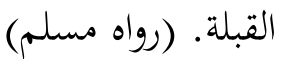

"Bercerita Abu Bakar bin Abi Saibah, bercerita 'Affan, bercerita Hammad bin Salamah, dari Tsabit dari Anas: "Bahwa sesungguhnya Rasulullah SAW (pada suatu hari) sedang shalat dengan menghadap Baitul Maqdis, kemudian turunlah ayat "Sesungguhnya Aku melihat mukamu sering menengadah ke langit, maka sungguh Kami palingkan mukamu ke kiblat yang kamu kehendaki. Palingkanlah mukamu ke arah Masjidil Haram". Kemudian ada seseorang dari bani Salamah bepergian menjumpai sekelompok sahabat sedang ruku' pada shalat fajar. Lalu ia menyeru "Sesungguhnya kiblat telah berubah". Lalu mereka berpaling seperti kelompok Nabi, yakni ke arah kiblat" (HR. Muslim).

c. Hadits riwayat Tirmidzi: ${ }^{10}$

$$
\begin{aligned}
& \text { وَعَنْ أَبِي هُرَيْرَة رضي الله عنه قَالَ : قَالَ رَسُولُ اللَّلَهِ صلى الله عليه وسلم مَا بَيْنَ }
\end{aligned}
$$

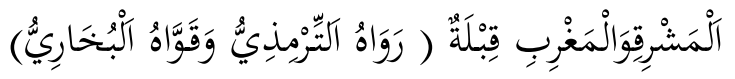

Dari Abi Hurairah r.a, bahwa Rasulullah Saw bersabda: "diantara timur dan barat adalah kiblat" (Diriwayatkan Termidzi dan dikuatkan oleh Bukhari).

\footnotetext{
${ }^{9}$ Mujab, p. 323.

${ }^{10}$ Mujab, p. 324.
} 


\section{ELFALAKY: Jurnal Ilmu Falak}

d. Hadits riwayat Bukhari: ${ }^{11}$

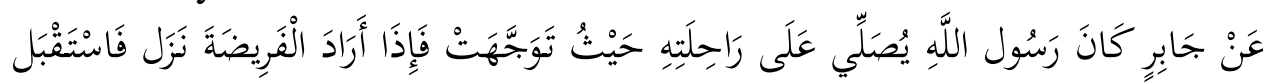

"Dari Jabir bin Abdillah radliyallâhu 'anhu bahwa Rasulullah SAW shalat di atas kendaraannya menghadap kemana pun kendaraannya itu menghadap. Namun bila beliau hendak shalat fardhu, maka beliau turun dan shalat menghadap kiblat" (HR. Bukhari).

\section{Konsep Astronomi}

\section{Definisi Astronomi}

Astronomi berasal dari bahasa Yunani yaitu "aster" yang berarti bintang, disebut juga ilmu falak atau kosmografi (kosmos yang berarti semesta). ${ }^{12}$ Ilmu astronomi atau yang biasa dikenal ilmu falak adalah ilmu yang mempelajari tentang benda-benda langit secara umum, seperti matahari, bulan, bintangbintang, dll. ${ }^{13}$ Dan juga mempelajari fenomena-fenomena angkasa, seperi gerhana matahari dan gerhana bulan, dll. ${ }^{14}$

Astronomi atau falak juga diartikan orbit atau lintasan, sebagaimana tertuang dalam Q.S Yasin (36) ayat 40 dan Q.S al-Anbiya (21) ayat $33::^{15}$

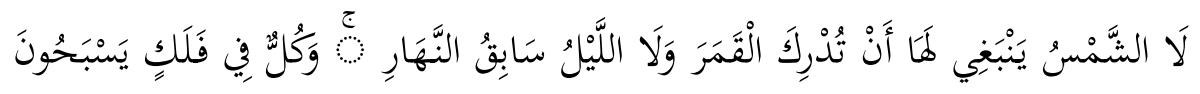

"Tidaklah mugkin bagi matahari mendapatkan bulan dan malam pun tidak dapat mendahului siang. Dan masing-masing beredar pada garis edarnya".

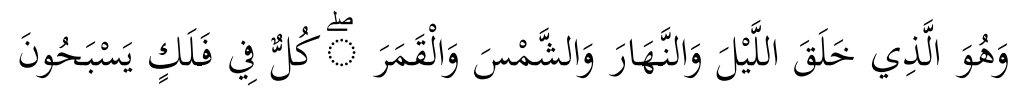

"Dan Dia-lah yang telah menciptakan malam dan siang, matahari dan bulan. Masing-masing keduanya itu berada di dalam garis edarnya”.

\footnotetext{
${ }^{11}$ Mujab, p. 324.

12 Cahya Fajar Agus Pamungkas, Ilmu Pelayaran Astronomi Untuk ANT-III Dan IV

${ }^{13}$ Watni Marpaung, Pengantar Ilmu Falak, (Jakarta: Prenadamedia Group, 2015), p. 3.

${ }^{14}$ Anton Ramadan, Islam Dan Astronomi (Jakarta: Bee Media Indonesia, 2009), p. 13.

15 A. Jamil, Ilmu Falak, 1st edn (Jakarta: Amzah, 2014), pp. 1-2.
} (Yogyakarta: Leutikaprio, 2016), p. 1. 


\section{ELFALAKY: Jurnal Ilmu Falak}

Vol. 4. Nomor 1. Tahun 2020 M / 1441

Dapat difahami, astronomi atau falak adalah ilmu yang membahas gejalagejala alam, seperti gerhana matahari, bulan, dll. Hal tersebut menjadi salah satu metode dalam menentukan arah kiblat.

\section{Bumi dan Koordinatnya}

Bumi dalam bahasa arabnya $\mathrm{Ardl}$, sedangkan dalam bidang astronomi disebut Earth (Inggris) atau Geo (Yunani) adalah salah satu benda langit di antara sembilan pelanet. Bentuknya mirip seperti bola dengan diameter $12.756 .776 \mathrm{~km}$ dari khatulistiwa dan jarak dari kutub ke kutub $12.713824 \mathrm{~km}$. Sedangkan jarak antara bumi dengan matahari sekitar 149. $674.000 \mathrm{~km}$ dibulatkan 150 juta $\mathrm{km} .{ }^{16}$

Sedangkan koordinat adalah nilai dalam menentukan kedudukan suatu benda langit pada bola langit. ${ }^{17}$ Untuk mengetahui arah kiblat, maka hal yang penting kita ketauhi adalah lintang tempat, bujur tempat, dan Lintang dan Bujur Kota Mekkah (Ka'bah)

a. Lintang Tempat ('Ardlul Balad)

Lintang tempat atau 'ardlul balad adalah jarak dari titik atau tempat yang kita inginkan sampai dengan khatulistiwa (equator) diukur dengan garis bujur. Lintang khatulistiwa adalah $0^{\circ}$ dan lintang titik kutub bumi adalah $90^{\circ}$. Untuk yang berada di sebelah utara khatulistiwa disebut lintang utara (LU) diberi tanda positif (+) sedangkan yang berada di sebelah selatan khatulistiwa disebut lintang selatan (LS) di beri tanda negarif (-). Jadi, nilai garis atau lintang yang diukur berkisar $0^{\circ}$ sampai dengan $90^{\circ}{ }^{18}$ Sebagaimana gambar di bawah ini:

16 Muhyiddin Khazin, Ilmu Falak Dalam Teori Dan Praktik (Semarang: Program Pascasarjana IAIN Walisongi Semarang, 2011), p. 39.

${ }_{17}^{17}$ Mahyuddin Khazin, Kamus Ilmu Falak (Jogjakarta: Buana Pustaka, 2005), p. 46.

${ }^{18}$ Sub Direktorat Pembinaan Syariah dan Hisab Rukyat Direktorat Urusan Agama Islam \& pembinaan Syariah Direktorat jendral Bimbingan Masyarakat Islam Kementrian Agama Republik Indonesia, Ilmu Falak Praktik (Jakarta: Sub Direktorat Pembinaan Syariah dan Hisab Rukyat Direktorat Urusan Agama Islam \& pembinaan Syariah Direktorat jendral Bimbingan Masyarakat Islam Kementrian Agama Republik Indonesia), p. 30. 


\section{ELFALAKY: Jurnal Ilmu Falak}

Vol. 4. Nomor 1. Tahun $2020 \mathrm{M} / 1441$

Gambar 1: Lintang Tempat

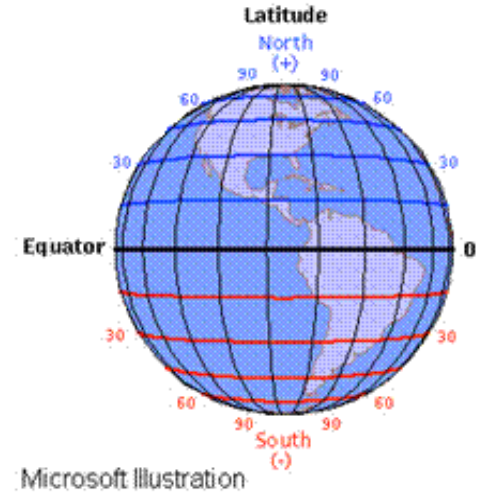

b. Bujur Tempat (Thulul Balad)

Bujur tempat atau thulul balad adalah jarak dari titik atau tempat yang kita inginkan ke garis bujur melalui kota Greenwich dekat dengan london. Untuk yang berada di sebelah barat kota Greenwich disebut bujur barat (BB) yang bertanda positif (+) dari $0^{\circ}$ sampai $180^{\circ}$. Untuk yang berada di sebelah timur kota Greenwich disebut bujur timur (BT) yang bertanda negatif (-) dari $0^{\circ}$ sampai $180^{\circ}$. Jadi, garis bujur dari $0^{\circ}$ sampai $180^{\circ}$, baik ke arah barat maupun kearah timur. ${ }^{19}$ Lihat gambar di bawah ini

Gambar 2: Bujur Tempat

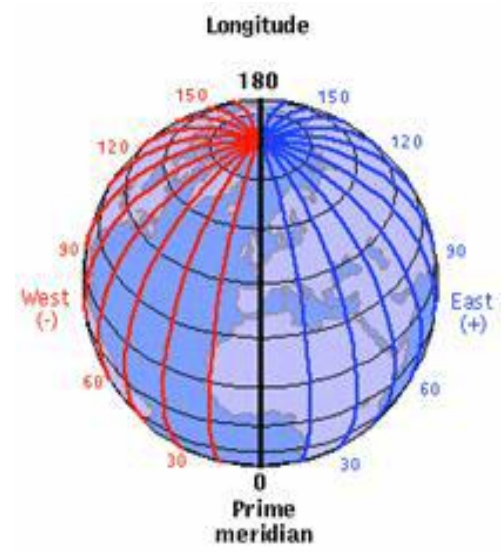

${ }^{19}$ Sub Direktorat Pembinaan Syariah dan Hisab Rukyat Direktorat Urusan Agama Islam \& pembinaan Syariah Direktorat jendral Bimbingan Masyarakat Islam Kementrian Agama Republik Indonesia, p. 30. 


\section{ELFALAKY: Jurnal Ilmu Falak}

Vol. 4. Nomor 1. Tahun $2020 \mathrm{M} / 1441$

c. Lintang dan Bujur Kota Mekkah (Ka'bah)

Besar data lintang Mekkah adalah $21^{\circ} 25^{\circ} 21.17^{\circ}$ LU dan Bujur Mekkah $39^{\circ} 49^{\circ} 34.56^{\circ}$ BT. Untuk nilai lintang dan bujur Ka'bah adalah tetap, sehingga kita tidak perlu mencari lagi seperti lintang tempat dan bujur tempat yang dicari arah kiblatnya.

3. Metode Penentuan Arah Kiblat

a. Rashd al-Qiblah (posisi matahari di atas ka'bah)

Posisi matahari di atas ka'bah (Rashd al-Qiblah) adalah suatu waktu tertentu yang digunakan dalam menetapkan atau mengecek kembali tempattempat yang dipakai untuk shalat (masjid, mushalla, rumah, kantor, dll). ${ }^{20}$ Waktu tersebut terjadi dua kali dalam satu tahun, yaitu setiap tanggal 28 Mei (jam 16:17:56 WIB) dan tanggal 16 Juli (jam 16:26:43 WIB). Fenomena rashd al-qiblah, sebagaimana gambar di bawah ini:

Gambar 3: Rashd al-Qiblah

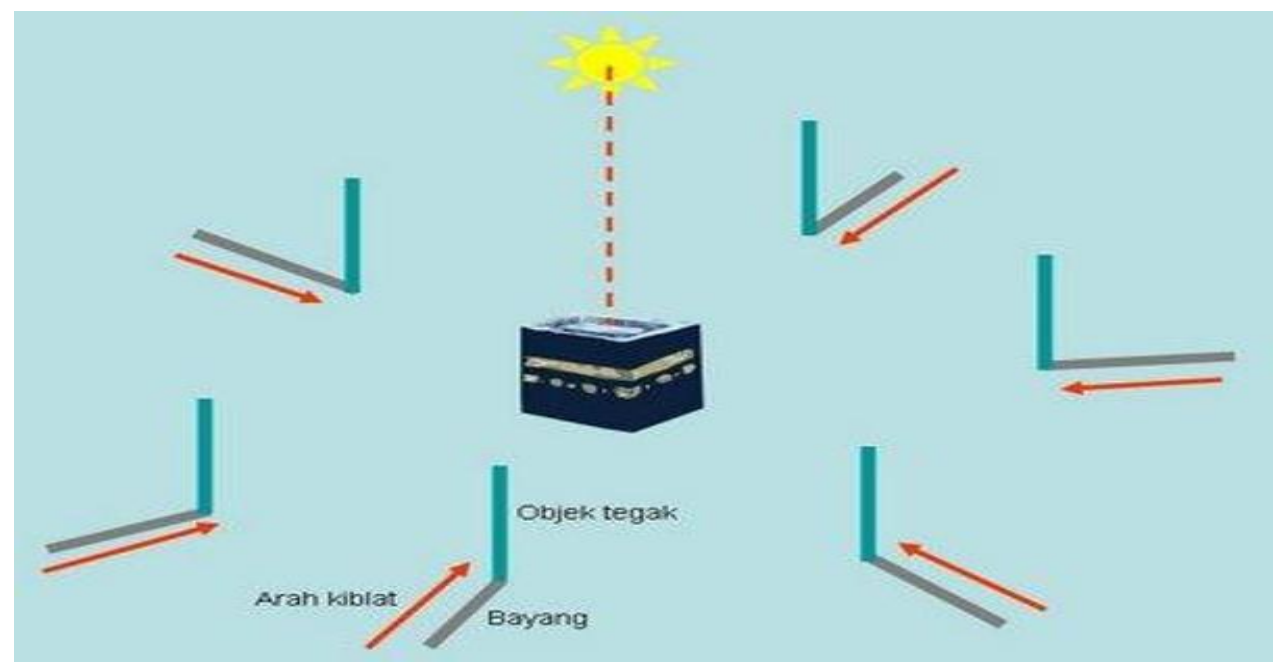

Dengan demikian, ketika matahari tepat di atas Ka'bah, maka objek yang terkena matahari itu pun akan menimbulkan bayangan. Bayangan itulah arah kiblat. metode ini, merupakan salah satu bentuk penentuan arah kiblat akurasi yang akurat.

\footnotetext{
${ }^{20}$ Haliyah, p. 118.
} 


\section{ELFALAKY: Jurnal Ilmu Falak \\ Vol. 4. Nomor 1. Tahun 2020 M / 1441}

b. Tongkat istiwa'

Tongkat istiwa' merupakan tongkat lurus yang biasa di tancapkan pada bidang datar dan tempat terbuka dengan mengandalkan matahari. ${ }^{21}$ Metode ini, memanfaatkan bayangan matahari sebelum atau sesudah tergelincirnya matahari (zawal), dengan tongkat istiwa kita bisa mendapatkan arah barat dan timur sejati. ${ }^{22}$

Bayangan matahari sebelum zawal maka akan menghasilkan arah barat dan bayangan matahari setelah zawal akan menghasilkan arah timur. Ketika sudah mendapatkan arah barat dan timur, untuk mendapatkan arah utara dan selatan yaitu dengan membuat garis berlawanan antara garis B dan $\mathrm{T}$ dengan diukur segitiga siku-siku $\left(90^{\circ}\right)$. Selanjutnya tinggal mencari titik $295^{\circ}$ dalam menentukan arah kiblat, khususnya di Indonesia. Lihat gambar di bawah:

\section{Gambar 4: Tongkat istiwa '}

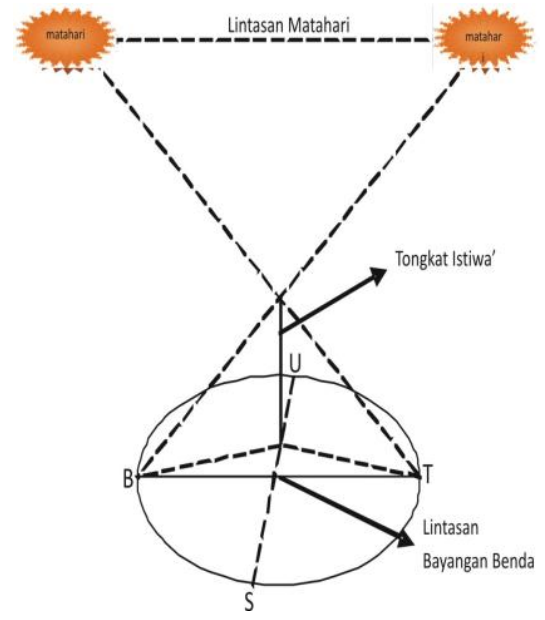

${ }^{21}$ Haliyah, p. 121.

${ }^{22}$ Jayusman, 'Akurasi Metode Penentuan Arah Kiblat: Kajian Fiqh Al-Ikhtilaf Dan Sains', Jurnal Asas, 6.1 (2014), p. 74. 


\section{ELFALAKY: Jurnal Ilmu Falak}

Vol. 4. Nomor 1. Tahun 2020 M / 1441

c. Kompas

Kompas adalah instrumen navigasi untuk menentukan arah relatif terhadap kutub magnetik bumi. ${ }^{23}$ Pengukuran arah kiblat dengan kompas memerlukan extra hati-hati dan penuh kecermatan, mengingat jarum kompas itu kecil dan peka terhadap medan magnit. ${ }^{24}$ Lihat gambar di bawah ini:

Gambar 5: Kompas

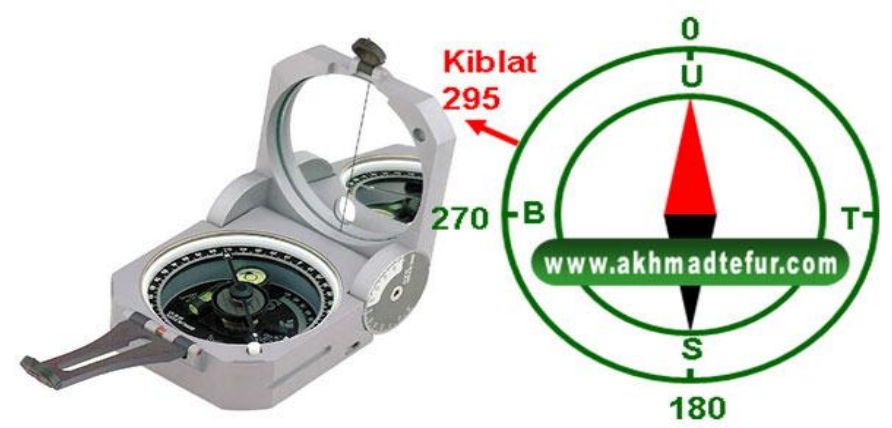

Untuk menggunakan kompas dengan baik, maka perlu diperhatikan: Pertama, siapkan kompas yang berfungsi dengan baik; kedua, siapkan koreksi deklinasi magnetik; ketiga, koreksikan deklinasi magnetik dengan cara menambahkannya pada hasil hitungan arah kiblat dengan perhitungan segitiga bola; keempat, letakkan kompas di tempat yang rata; dan baca arah kompas sesuai dengan nilai arah yang telah dikoreksi deklinasi magnetiknya. ${ }^{25}$

d. Segitiga Bola (Spherical Trigonometri)

Segitiga bola atau disebut dengan istilah spherical trigonometri adalah ilmu ukur sudut bidang datar yang di aplikasikan pada permukaan bulat. Ilmu ini pertama kali dikembangkan para ilmuwan muslim dari Jazirah Arab

${ }^{23}$ M Z Ibrahim and M Z Norashikin, 'Mobile Qibla and Prayer Time Finder Using External GPS and Digital Compass', 6 (p. 141).

${ }^{24}$ Mutoha Arkanuddin, 'Teknik Penentuan Arah Kibalat', p. 121.

${ }^{25}$ Haliyah, p. 121. 


\section{ELFALAKY: Jurnal Ilmu Falak}

Vol. 4. Nomor 1. Tahun 2020 M / 1441

seperti al-Battani dan al Khawarizmi dan terus berkembang, hingga menjadi sebuah ilmu dengan julukan Geodesi. ${ }^{26}$

Untuk menentuan arah kiblat dengan metode ini, ada tiga titik yang diperlukan, yaitu titik A sebagai tempat Ka'bah; titik B sebagai tempat yang akan di tentukan kiblatnya; dan titik $\mathrm{C}$ sebagai titik kutub utara. Sebagaimana gambar di bawah ini :

Gambar 6: Segitiga Bola

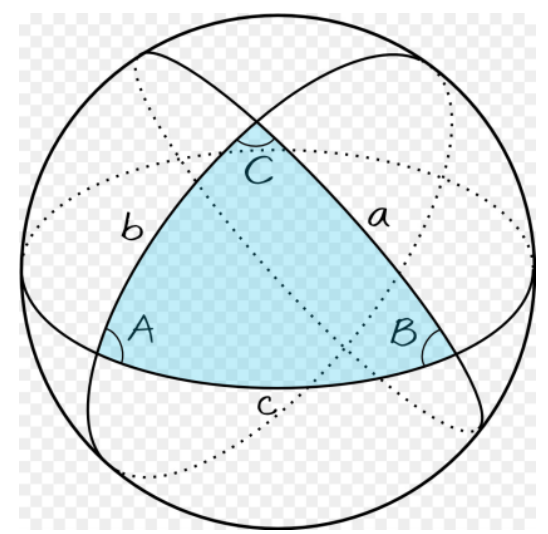

Cara perhitungan segitiga bola, untuk lintang dan bujur mekkah memiliki nilai tetap. Lintang Mekkah $=21^{\circ} 25^{\prime}$, Bujur Mekkah $=39^{\circ} 50^{\prime}$. Dan nilai tempat berbeda-beda tergantung tempat masing-masing, pada kali ini adalah kota Ketapang. Lintang Ketapang $=91^{\circ} 50^{\prime}$ dan bujur Ketapang $=109^{\circ}$ $58^{\prime}$. Lebih lanjut, $\mathrm{a}=90^{\circ}-\left(-1^{\circ} 50^{\prime}\right)=91^{\circ} 50^{\prime} . \mathrm{b}=90^{\circ}-21^{\circ} 25^{\prime}=68^{\circ} 35^{\prime} . \mathrm{c}=$ $109^{\circ} 58^{\prime}-39^{\circ} 50^{\prime}=70^{\circ} 8^{\prime}$.

Rumus: $\operatorname{Cotg} B=\underline{\sin a \operatorname{cotg} b-\cos a \cos c}$

Sin c

$\operatorname{Cotg} \mathbf{B}=\frac{\sin 91^{\circ} 50^{\prime} \times \operatorname{cotg} 68^{\circ} 35^{\prime}-\cos 91^{\circ} 50^{\prime} \times \cos 70^{\circ} 8^{\prime}}{\sin 70^{\circ} 8^{\prime}}$

$=67^{\circ} 22^{\prime} 16,93^{\prime \prime}$ (Utara - Barat)

$=22^{\circ} 37^{\prime} 43,07^{\prime \prime}$ (Barat - Utara)

$=292^{\circ} 37^{\prime} 43,0^{\prime \prime}(\mathrm{UTSB})$

\footnotetext{
${ }^{26}$ Arkanuddin.
} 


\section{ELFALAKY: Jurnal Ilmu Falak}

Vol. 4. Nomor 1. Tahun $2020 \mathrm{M} / 1441$

e. Theodolit

Theodolit adalah salah satu alat ukur sudut yang paling akurat dalam menentukan arah kiblat berbasis digital. Tidak hanya theodolit saja, ada Total Station yang dilengkapi dengan piranti GPS sebagai pemandu arah dan posisi. Mengenai sistem kerjanya sama dengan metode yang lain yaitu dengan mengandalkan matahari, untuk menetahui azimut matahari, dari posisi tersebut di dapati titik utara sejati. ${ }^{27}$

Gambar 6: Theodolit

\section{f. Global Positioning System (GPS)}

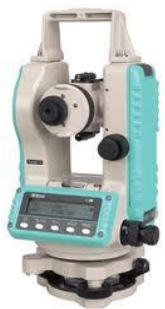

Menurut Hasanuddin Abidin dalam Anisah Budiwati, global positioning system disingkat GPS adalah sistem radio navigasi dan penentuan posisi dengan bantuan satelit. ${ }^{28}$ GPS ini, merupakan alat untuk mengukur koordinat dengan menggunakan satelit yang bisa mengetahui posisi lintang, bujur, jarak, ketinggian tempat, dll. ${ }^{29}$

Gambar 7: GPS

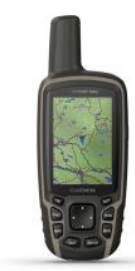

${ }^{27}$ Sub Direktorat Pembinaan Syariah dan Hisab Rukyat Direktorat Urusan Agama Islam \& pembinaan Syariah Direktorat jendral Bimbingan Masyarakat Islam Kementrian Agama Republik Indonesia, p. 784.

${ }^{28}$ Anisah Budiwati, 'Tongkat Istiwa', Global Positioning System (GPS) dan Google Earth Untuk Menentukan Titik Koordinat Bumi dan Aplikasinya dalam Penentuan Arah Kiblat', Al-Ahkam, 26.1 (2016), 65 (p. 73) <https://doi.org/10.21580/ahkam.2016.26.1.808>.

${ }^{29}$ Haliyah, p. 123. 
g. Google Earth

Google Earth (GE) adalah sebuah program virtual yang bisa menampilkan semua gambar di dunia yang didapat dari satelit, fotografi udara dan aplikasi Geographic Information System (GIS). Aplikasi ini berbeda dengan peta biasa yang ditampilkan dalam bentuk 2D, GE menampilkan keseluruhan gambar dalam kerangka bola dunia dan dapat mengakses kota-kota besar secara detail. Gambar-gambar yang dihasilkannya pun memiliki resolusi tinggi sehingga gambar gedung-gedung, orang, bahkan mobil dapat dilihat di kota-kota dan negara bagian tertentu. ${ }^{30}$

Gambar 8: Google Earth

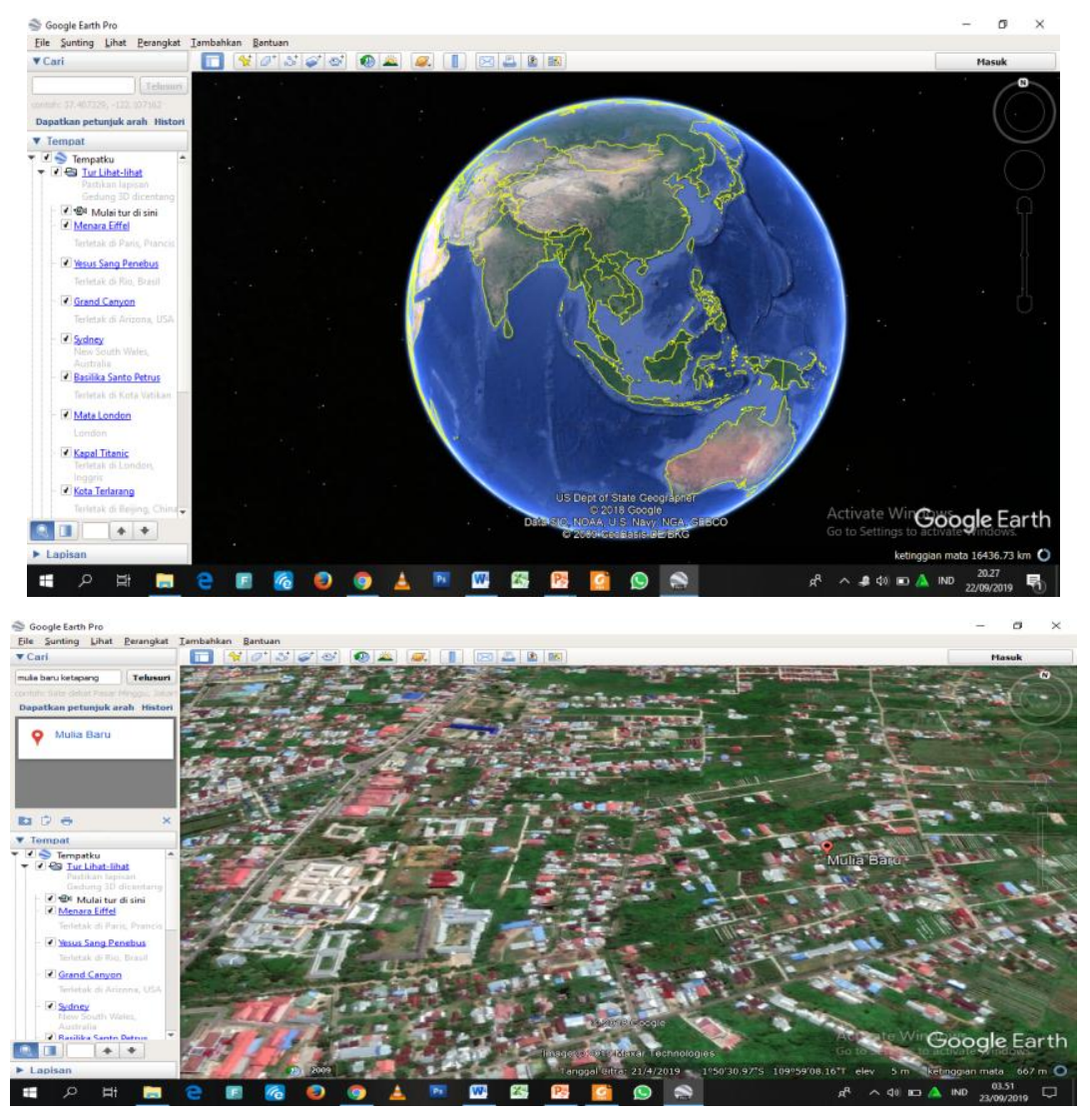

\footnotetext{
${ }^{30}$ Budiwati, p. 77.
} 


\section{ELFALAKY: Jurnal Ilmu Falak}

Vol. 4. Nomor 1. Tahun $2020 \mathrm{M} / 1441$

\section{E. Integrasi Teks Syar'i dan Teori Astronomi dalam Menentukan Arah Kiblat}

Melihat berbagai definisi arah kiblat dalam literatur ilmu falak. Arah kiblat adalah arah terdekat dari titik atau tempat menuju Ka'bah dan setiap Muslim wajib menghadap kiblat ketika melaksanakan shalat. Namun, belum ada rumusan baku terhadap definisi arah menghadap kiblat dalam istilah fiqh. Artinya, definisi arah kiblat yang ada hanya mendefinisikan tentang kiblat, namun belum ada yang mendefinisikan maksud arah sebenarnya. Apakah berupa arah yang terbentuk dalam suatu sudut pada azimuth kiblat dengan sudut tetap namun menempuh jarak yang jauh, ataukah arah dengan sudut tidak tetap namun jarak yang ditempuh merupakan jarak terdekat?.

Ayat al-Qur'an (Q.S al-Baqarah [2] ayat 144, 149-150) yang telah disebutkan di pembahasan sebelumnya menyebutkan "fawalli wajhaka syatral masjidil haram". Kata "fawalli" adalah kata perintah yang berarti "maka palingkanlah". Artinya, yang dimaksud memalingkan, yaitu memalingkan wajah dan aggota badan yang bergerak untuk menghadap kiblat. jadi, definisi arah kiblat dari segi tafsir al-Qur'an adalah arah menghadap, bukan arah perjalanan atau arah yang lain. ${ }^{31}$

Maka dari itu, ada tiga teori perhitungan arah kiblat suatu tempat di permukaan bumi, yaitu teori trigonometri bola, teori geodesi, dan teori navigasi. Ketiga teori ini memiliki definisi arah masing-masing. Teori trigonometri bola dan teori geodesi adalah arah yang mengikuti garis yang mempunyai arah sudut tidak tetap (orthodrom) dengan jarak tempuh terdekat. Sedangkan teori navigasi adalah arah yang mengikuti garis yang mempunyai arah sudut tetap (loxodrom) dengan jarak tempuh yang jauh. ${ }^{32}$

Adapun perbedaan dari teori trigonometri bola dan geodasi dengan teori navigasi dalam menentukan arah kiblat, seperti arah kiblat Kota Hanoi (Vietnam).

\footnotetext{
${ }^{31}$ Ahmad Izzuddin, 'Metode Penentuan Arah Kiblat Dan Akurasinya. Conference Procedings of Annual International Conference on Islamic Studies (AICIS XII)’, 2012, p. 21.

${ }^{32}$ Izzuddin, p. 773.
} 
Kota Hanoi di Vietnam ini secara geografis memiliki lintang yang hampir sama dengan lintang Ka'bah. Perhatikan gambar di bawah ini :

Gambar 9: Kiblat Kota Hanoi (Vietnam)

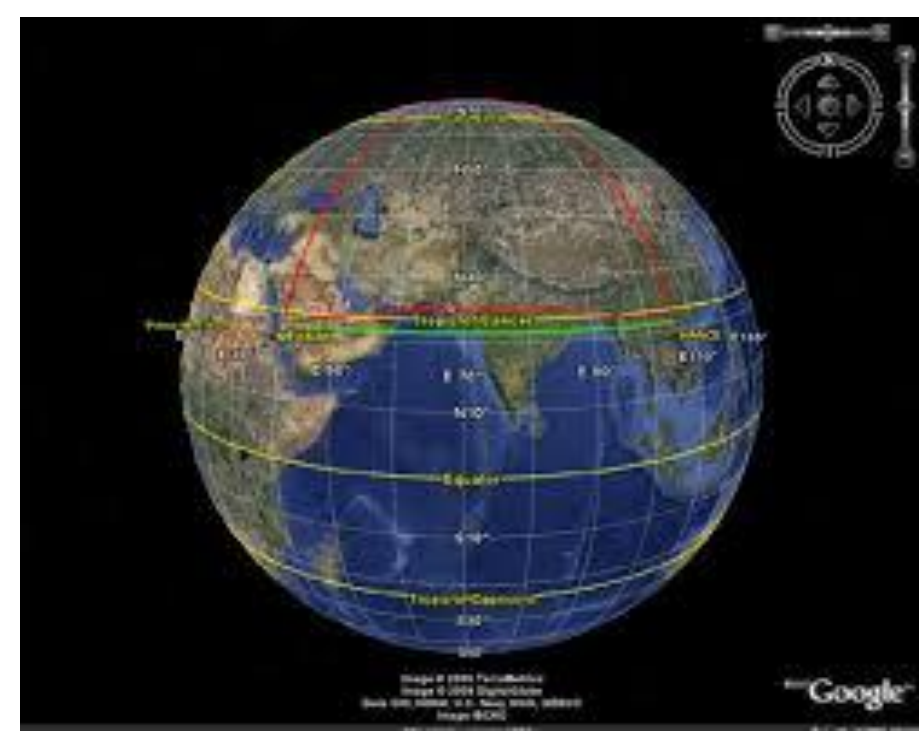

Dari gambar di atas, posisi Hanoi dan Mekkah berada pada posisi yang sejajar (garis berwarna hijau), dihubungkan oleh garis lintang yang sama melalui lingkaran kecil (small circle)/ garis loxodrom. Begitu juga jika dilihat di peta, Hanoi dan Mekkah berada dalam garis yang lurus. Sehingga berdasarkan teori navigasi, arah kiblat Kota Hanoi cukup dengan mengarah ke Barat maka akan sampai ke Mekkah. Dengan demikian, sudut yang terbentuk akan tetap (konstan) karena mengikuti lingkaran kecil (small circle) walaupun jarak yang dilalui akan lebih jauh bila dibandingkan dengan hasil teori trigonometri bola dan teori geodesi.

Dalam penjelasan sebelumnya telah disebutkan bahwa definisi arah dalam istilah fiqh menghadap kiblat adalah arah yang memiliki makna "arah menghadap", bukan arah perjalanan. Sedangkan arah yang digunakan dalam teori navigasi adalah arah yang digunakan dalam perjalanan karena menggunakan panduan sudut arah yang tetap dan memposisikan bumi dalam bentuk datar. Arah ini digunakan apabila kita bepergian menuju Mekkah dengan panduan sudut arah 


\section{ELFALAKY: Jurnal Ilmu Falak}

Vol. 4. Nomor 1. Tahun $2020 \mathrm{M} / 1441$

yang tetap (misalnya ke arah barat). Sedangkan dalam melaksanakan ibadah shalat, posisi mushalli tidak bergerak menuju Mekkah, tapi berdiri tegak di tempat untuk menghadap Ka'bah di Mekkah. Oleh karena itu pemaknaan arah kiblat adalah arah menghadap, bukan arah perjalanan. Dengan demikian, teori navigasi tidak dapat digunakan dalam perhitungan arah kiblat karena arah yang digunakan dalam teori navigasi adalah arah perjalanan.

\section{F. Penutup}

Berdasarkan deskripsi kajian ini dapat disimpulkan bahwa menghadap kiblat adalah kewajiban bagi seorang muslim ketika melaksanakan shalat, sebagaimana tertuang dalam Q.S al- Baqarah (2) ayat 144, 149-150 dan hadits-hadits yang telah disebutkan pada pembahasan sebelumnya. Sehingga para ulama sepakat bahwa salah satu syarat sahnya shalat adalah menghadap kiblat.

Untuk menghadap kiblat dengan tepat ke Ka'bah, ilmu astronomi atau falak mengambil peran dalam menentukan kiblat secara tepat dengan bermacam-macam metode (klasik dan modern). Metode klasik seperti rashd al-qiblah (posisi matahari di atas ka'bah), menggunakan tongkat istiwa', dan berdasarkan fenomena bayangan matahari harian. Sedangkan metode yang bersifat modern, diantaranya dengan menggunakan: kompas, ilmu ukur segitiga bola (spherical trigonometri), theodolit, Global Positioning System (GPS), google earth, dan lain-lain.

Kemudian ada tiga tiori dalam astronomi, yaitu teori trigonometri bola, teori geodesi, dan teori navigasi. Untuk teori naviasi tidak dapat digunakan dalam perhitungan arah kiblat karena arah yang digunakan dalam teori navigasi adalah arah perjalanan dan teori navigasi menggunakan panduan sudut arah yang tetap dan memposisikan bumi dalam bentuk datar. Sedangkan Kata "fawalli" dalam Q. S al- Baqarah (2) ayat 144, 149-150 adalah kata perintah yang berarti "maka palingkanlah". Artinya, yang dimaksud memalingkan, yaitu memalingkan wajah dan aggota badan yang bergerak untuk menghadap kiblat. Makna memalingkan ini sejalan dengan teori trigonometri bola dan teori geodesi. 
ELFALAKY: Jurnal Ilmu Falak

Vol. 4. Nomor 1. Tahun $2020 \mathrm{M} / 1441$

\section{DAFTAR PUSTAKA}

Agus Pamungkas, Cahya Fajar, Ilmu Pelayaran Astronomi Untuk ANT-III Dan IV (Yogyakarta: Leutikaprio, 2016)

Arkanuddin, Mutoha, 'Teknik Penentuan Arah Kibalat'

Bashori, M. Hadi, Pengantar Ilmu Falak (Jakarta Timur: Pustaka al-Kautsar, 2015)

Budiwati, Anisah, 'Tongkat Istiwa', Global Positioning System (GPS) dan Google Earth Untuk Menentukan Titik Koordinat Bumi dan Aplikasinya dalam Penentuan Arah Kiblat', Al-Ahkam, $26.1 \quad$ (2016), 65 <https://doi.org/10.21580/ahkam.2016.26.1.808>

Haliyah, Dahlia, 'Penentuan Arah Kiblat (Dari Metode Klasik Ke Modern)', Jurnal Hukum Islam, 1.2 (2013)

Ibrahim, M Z, and M Z Norashikin, 'Mobile Qibla and Prayer Time Finder Using External GPS and Digital Compass', 6

Izzuddin, Ahmad, 'Metode Penentuan Arah Kiblat Dan Akurasinya. Conference Procedings of Annual International Conference on Islamic Studies (AICIS XII)', 2012

Jamil, A., Ilmu Falak, 1st edn (Jakarta: Amzah, 2014)

Jayusman, 'Akurasi Metode Penentuan Arah Kiblat: Kajian Fiqh Al-Ikhtilaf Dan Sains', Jurnal Asas, 6.1 (2014)

Khazin, Mahyuddin, Kamus Ilmu Falak (Jogjakarta: Buana Pustaka, 2005)

Khazin, Muhyiddin, Ilmu Falak Dalam Teori Dan Praktik (Semarang: Program Pascasarjana IAIN Walisongi Semarang, 2011)

Marpaung, Watni, Pengantar Ilmu Falak, (Jakarta: Prenadamedia Group, 2015)

Mujab, Sayful, 'Kiblat dalam Perspektif Madzhab-Madzhab Fiqh', Pemikiran Hukum dan Hukum Islam, 5.2 (2014), 27

Munawwir, Ahmad Warson, Kamus Al-Munawwir (Surabaya: Pustaka Progressif, 1997)

Pendididkan Nasional, Pusat Bahasa Dapartemen, Kamus Bahasa Indonesia (Jakarta: Pusat Bahasa, 2008) 


\section{ELFALAKY: Jurnal Ilmu Falak}

Vol. 4. Nomor 1. Tahun $2020 \mathrm{M} / 1441$

Ramadan, Anton, Islam Dan Astronomi (Jakarta: Bee Media Indonesia, 2009)

Sub Direktorat Pembinaan Syariah dan Hisab Rukyat Direktorat Urusan Agama Islam \& pembinaan Syariah Direktorat jendral Bimbingan Masyarakat Islam Kementrian Agama Republik Indonesia, Ilmu Falak Praktik (Jakarta: Sub Direktorat Pembinaan Syariah dan Hisab Rukyat Direktorat Urusan Agama Islam \& pembinaan Syariah Direktorat jendral Bimbingan Masyarakat Islam Kementrian Agama Republik Indonesia)

Su'ud, Abu, Islamologi: Sejarah, Ajaran, dan Peranannya dalam Peradaban Umat Manusia (Jakarta: Rineka Cipta, 2003) 